\title{
Korelasi plak, CIMT, dan skor kalsium dengan derajat stenosis arteri koroner pada pasien dislipidemia
}

\author{
Erman Muliawan ${ }^{1}$, Nikmatia Latief ${ }^{1}$, Sri Asriyani ${ }^{1}$, Andi Alfian Zainuddin ${ }^{2}$, Muzakkir Amir ${ }^{3}$, \\ Mirna Muis ${ }^{1}$ \\ 1. Departemen Radiologi, Fakultas Kedokteran, Universitas Hasanuddin, Makassar; 2. Departemen \\ IKM \& IKK, Fakultas Kedokteran, Universitas Hasanuddin, Makassar; 3. Departemen Kardiologi, \\ Fakultas Kedokteran, Universitas Hasanuddin, Makassar
}

Korespondensi: Erman Muliawan; email: erman muliawan@yahoo.com

\begin{abstract}
Abstrak
Tujuan: Mengetahui korelasi plak, ketebalan tunika intima-media arteri karotis berdasarkan ultrasonografi dan skor kalsium total dengan derajat stenosis arteri koroner berdasarkan MSCT-scan kardiak pada pasien dislipidemia. Metode: Cross-sectional, dilakukan di Instalasi Radiologi Sentral RSUP dr. Wahidin Sudirohusodo, Makassar, mulai bulan Juli 2018 sampai Juli 2019. Sampel sebanyak 32 orang dengan usia $>18$ tahun dan memiliki riwayat dislipidemia. Metode statistik yang digunakan uji korelasi Spearman. Hasil: Terdapat korelasi antara kejadian plak, ketebalan tunika intima-media arteri karotis dan total calcium score dengan derajat stenosis arteri koroner, dimana nilai $\mathrm{p}$ masingmasing secara berurutan yaitu $0,017(<0,05),<0,0001$, dan $<0,0001$ dan nilai $r$ masing-masing yaitu $0,418,0,65$, dan 0,882. Simpulan: Skor kalsium total merupakan suatu penanda independen risiko kejadian kardiovaskular, lebih superior dibandingkan evaluasi arteri karotis. Terdapatnya nilai skor kalsium total menunjukkan adanya suatu penyakit arteri koroner namun tidak memprediksi obstruksi luminal. Di samping itu, keadaan dinding arteri karotis juga dapat mencerminkan keadaan dinding arteri koroner sehingga dapat digunakan sebagai penanda terjadinya aterosklerosis pada pembuluh darah jantung pada daerah yang belum memiliki fasilitas skor kalsium total.
\end{abstract}

Kata kunci: dislipidemia; plak arteri karotis; ketebalan tunika intima-media arteri karotis; total calcium score; derajat stenosis arteri koroner

\section{Abstract}

Objective: To assess correlation among plaque, carotid intimal-media thickness using carotid ultrasonography and total calcium score with coronary artery stenosis using cardiac MSCT-scan in dyslipidemia patient. Method: Cross-sectional, conducted in Central Radiology Department of dr. Wahidin Sudirohusodo Central General Hospital, Makassar, from July 2018 until July 2019. The sample was 32 people aged more than 18-year-old. The methods were Spearman test. Results: correlation among plaque incidence, carotid intimal-media thickness and total calcium score with coronary artery stenosis, which $p$ value respectively were $0.17(<0.05),<0.0001$, and $<0.001$ also the $r$-value were 0.418 , 0.65 , and 0.882. Conclusions: Total calcium score is independent marker of cardiovascular risk, superior from carotid artery ultrasound. Total calcium score suggests coronary artery disease but not predict luminal obstruction. However, carotid artery wall also can represent coronary artery wall so can used as atherosclerotic marker in coronary artery in regions that do not yet have total calcium score facility.

Keywords: dyslipidemia; carotid artery plaque; carotid intimal-media thickness; total calcium score; coronary artery stenosis degree 


\section{PENDAHULUAN}

Dislipidemia merupakan faktor risiko paling penting terbentuknya aterosklerosis yang merupakan penyebab terjadinya penyakit kardiovaskular. ${ }^{1}$ Berbagai teknik non invasif digunakan untuk menilai aterosklerosis seperti plak dan ketebalan tunika intima-media arteri karotis menggunakan ultrasonografi arteri karotis, serta total calcium score dan derajat stenosis arteri koroner menggunakan MSCT-scan kardiak. ${ }^{1-3} \quad$ Ultrasonografi karotis dapat digunakan untuk mengidentifikasi perubahan aterosklerosis tahap awal pada dinding arteri yang non invasif. Pengukuran ketebalan tunika intima-media (Carotid Intimal-Media Thickness/CIMT) dan deteksi adanya pembentukan plak telah digunakan sebagai indikator sensitif dan dini adanya aterosklerosis tahap awal. ${ }^{1} \mathrm{Di}$ Indonesia, alat CT-scan belum tersedia secara luas di daerah-daerah terpencil dan merupakan alat modalitas menggunakan radiasi pengion. Dengan penelitian ini diharapkan pemeriksaan ultrasonografi arteri karotis dapat digunakan sebagai pemeriksaan yang aman, non invasif, cepat dan akurat dalam memprediksi adanya stenosis arteri koroner. Skor Agatston telah ditunjukkan berkaitan dengan tingkat keparahannya penyakit arteri koroner. Bagaimanapun, hubungan antara banyaknya kalsifikasi arteri koroner dengan keparahan stenosis arteri koroner belum sepenuhnya diteliti. Tujuan penelitian ini untuk menilai faktor yang paling berkorelasi dengan derajat stenosis arteri koroner. Hipotesis yang diajukan dalam penelitian ini adalah ada korelasi antara plak, ketebalan tunika intima-media arteri karotis berdasarkan ultrasonografi dan total calcium score dengan derajat stenosis arteri koroner berdasarkan MSCT kardiak.

\section{METODE}

Penelitian ini merupakan cross-sectional, dilakukan di instalasi radiologi sentral RSUP dr. Wahidin Sudirohusodo, Makassar mulai bulan Juli 2018 sampai Juli 2019. Sampel sebanyak 32 orang dengan usia $>18$ tahun dan memiliki riwayat dislipidemia. Kriteria eksklusi penelitian ini yaitu hipertensi, usia $<18$ tahun, di-seksi arteri karotis dan keadaan umum pasien yang tidak memungkinkan dilakukan ultrasonografi arteri karotis dan MSCT-scan kardiak. Pemeriksaan dilakukan dengan terlebih dahulu identifikasi dan peng-input-an data pasien serta penjelasan mengenai pemeriksaan yang akan dilakukan, jika pasien setuju kemudian dilakukan pengisian dan penandatanganan informed consent oleh pasien. Kemudian pasien akan dilakukan pemeriksaan ultrasonografi arteri karotis dan selanjutnya dilakukan pemeriksaan MSCT-scan kardiak. Pada pemeriksaan ultrasonografi arteri karotis, subyek diposisikan terlentang (supinasi) dengan leher di-ekstensi-kan dan kepala berpaling ke sisi yang kontralateral dari sisi yang diperiksa, sehingga memungkinkan akses maksimal pada arteri karotis. Ketika dinding arteri karotis divisualisasikan oleh ultrasonografi B-mode, tampak karakteristik echo ganda dari tunika intima- 
media arteri karotis. Adanya plak arteri karotis berdasarkan kriteria ARIC (Atherosclerosis Risk In Communities) yaitu sedikitnya dua dari kriteria berikut ini: 1). CIMT >1,5 mm; 2) perubahan kontur permukaan dinding arteri karotis; 3) peningkatan fokal echogenicity dan ketebalan dinding arteri karotis (>50\%) dibandingkan dengan CIMT sekitar. ${ }^{2}$ CIMT tampak sebagai jarak antara dua garis echogenic pada dinding jauh, garis echogenic pertama yaitu lumen-intima dan garis echogenic kedua yaitu mediaadventitia). Pengukuran CIMT dilakukan pada arteri karotis komunis bilateral, panjang segmen yang dievaluasi sekitar 1 $\mathrm{cm}$ dan dicari yang paling tebal tunika intimanya. Nilai CIMT yang diambil yaitu rata-rata dari nilai CIMT kedua arteri karotis komunis. ${ }^{4}$ Penghitungan skor kalsium total berdasarkan MSCT-scan kardiak dengan menggunakan metode Agatston dan dikelompokkan menjadi: absen (0); minimal (1-100); sedang (101400); berat (>400)..$^{5}$ Derajat stenosis arteri koroner dihitung berdasarkan software GE dan dikelompokkan berdasarkan keparahan derajat stenosis-nya (klasifikasi Sayols-Baixeras) yaitu: tidak ada stenosis (0\%); stenosis minimal (1-24\%); stenosis ringan (25-49\%); stenosis sedang (50-69\%); stenosis berat (70-99\%); dan total oklusi (100\%). ${ }^{6}$ Penelitian ini memenuhi persyaratan etik dan mendapat persetujuan dari komisi etik fakultas kedokteran Universitas Hasanuddin, Makassar. Metode statistik yang digunakan yaitu uji korelasi Spearman.

\section{HASIL DAN PEMBAHASAN}

Distribusi sampel berdasarkan jenis kelamin, penderita dislipidemia sedikit lebih banyak ditemukan pada jenis kelamin laki-laki. Distribusi berdasarkan umur, penderita dislipidemia ditemukan lebih banyak pada umur 41-50 dan 51-60 tahun. Distribusi berdasarkan riwayat kebiasaan merokok, penderita dislipidemia sedikit lebih banyak ditemukan pada yang tidak merokok. Seluruh penderita dislipidemia yang merokok adalah laki-laki. Distribusi berdasarkan riwayat diabetes melitus, penderita dislipidemia lebih banyak ditemukan pada yang memiliki riwayat DM. Distribusi selengkapnya dapat dilihat pada tabel 1.

Tabel 1. Distribusi Sampel Berdasarkan Demografi

\begin{tabular}{cccc}
\hline & Kategori & $\mathrm{N}$ & $\%$ \\
\hline Jenis Kelamin & Laki-laki & 17 & $53 \%$ \\
& Perempuan & 15 & $47 \%$ \\
Umur (tahun) & $21-30$ & 1 & $3 \%$ \\
& $31-40$ & 3 & $9 \%$ \\
& $41-50$ & 11 & $34,5 \%$ \\
& $51-60$ & 11 & $34,5 \%$ \\
Merokok & $61-70$ & 5 & $16 \%$ \\
& $71-80$ & 1 & $3 \%$ \\
Diabetes & Ya & 13 & $41 \%$ \\
Mellitus & Tidak & 19 & $59 \%$ \\
& Ya & 4 & $13 \%$ \\
& Tidak & 28 & $87 \%$ \\
\hline
\end{tabular}

Pada tabel 2-5 memperlihatkan distribusi sampel berdasarkan kejadian plak arteri karotis, nilai CIMT rata-rata, total calcium score dan derajat stenosis arteri koroner. Tabel 6 memperlihatkan korelasi antara masing-masing kejadian plak, CIMT dan total calcium score dengan derajat stenosis arteri koroner. Hasil analisis korelasi plak 
arteri karotis dengan derajat stenosis arteri koroner, diperoleh nilai $P$ sebesar 0,017 $(<0,05)$ maka dapat disimpulkan bahwa ada korelasi bermakna dan memiliki kekuatan korelasi sedang dengan nilai $r$ sebesar 0,418. Korelasi antara CIMT dengan derajat stenosis arteri koroner diperoleh nilai $P$ sebesar $<0,0001$ maka dapat disimpulkan bahwa ada korelasi yang bermakna antara CIMT dengan derajat stenosis arteri koroner dan memiliki kekuatan korelasi kuat dengan nilai $r$ sebesar 0,65 . Korelasi antara total calcium score dengan derajat stenosis arteri koroner diperoleh nilai $\mathrm{P}$ sebesar $<0,0001$ maka dapat disimpulkan bahwa ada korelasi yang bermakna antara total calcium score dengan derajat stenosis arteri koroner dan memiliki kekuatan korelasi sangat kuat dengan nilai $r$ sebesar 0,882 .

Tabel 2. Distribusi sampel berdasarkan kejadian plak arteri karotis

\begin{tabular}{lccc}
\hline & Kategori & N & $\%$ \\
\hline Plak arteri & Ada & 7 & $22 \%$ \\
karotis & Tidak & 25 & $78 \%$ \\
\hline
\end{tabular}

Tabel 3. Distribusi sampel berdasarkan CIMT

\begin{tabular}{lcccc}
\hline & Min. & Maks. & $\begin{array}{c}\text { Rata- } \\
\text { rata }\end{array}$ & SD \\
\hline $\begin{array}{l}\text { CIMT } \\
\text { rata-rata } \\
(\mathrm{mm})\end{array}$ & 0,45 & 1,45 & 0,77 & 0,24 \\
\hline
\end{tabular}

Tabel 4. Distribusi sampel berdasarkan Total Calcium Score

\begin{tabular}{lcc}
\hline \multicolumn{1}{c}{ Calcium score } & $\mathrm{N}$ & $\%$ \\
\hline 0 (tidak ada plak) & 17 & $53 \%$ \\
$1-100$ (minimal) & 8 & $25 \%$ \\
$101-400$ (sedang) & 4 & $12,5 \%$ \\
$>400$ (berat) & 3 & $9,5 \%$ \\
\hline
\end{tabular}

Tabel 5. Distribusi sampel berdasarkan derajat stenosis arteri koroner

\begin{tabular}{lcc}
\hline $\begin{array}{l}\text { Derajat stenosis arteri } \\
\text { koroner }\end{array}$ & $\mathrm{N}$ & $\%$ \\
\hline Tidak ada stenosis (0\%) & 14 & $43,75 \%$ \\
Stenosis minimal (1-24\%) & 3 & $9,375 \%$ \\
Stenosis ringan (25-49\%) & 4 & $12,500 \%$ \\
Stenosis sedang (50-69\%) & 4 & $12,500 \%$ \\
Stenosis berat (70-99\%) & 7 & $21,875 \%$ \\
Total oklusi (100\%) & 0 & 0 \\
\hline
\end{tabular}

Hasil penelitian didapatkan jumlah sampel yaitu laki-laki sebanyak 17 orang (53\%) dan perempuan 15 orang (47\%) yang mengalami dislipidemia. Berdasarkan statistik WHO, prevalensi dislipidemia pada orang dewasa berumur $\geq 25$ tahun di Indonesia sekitar $36 \%$ yaitu 33,1\% pada laki-laki dan $38,2 \%$ pada perempuan. ${ }^{7}$ Namun terdapat juga penelitian di China yang menyatakan bahwa prevalensi dislipidemia pada laki-laki sedikit lebih tinggi dibandingkan dengan perempuan (51,38\%:48,62\%) pada tahun $2014 .^{8}$ Pada sampel yang didapatkan jumlah laki-laki sedikit lebih banyak daripada perempuan, mungkin hal ini berkaitan dengan sedikitnya jumlah sampel yang diambil sehingga tidak menggambarkan prevalensi yang sebenarnya.

Rentang usia dislipidemia paling banyak terjadi pada umur 41-50 dan 51-60 tahun sebanyak masing-masing 11 orang $(34,5 \%)$. Karakteristik sampel ini sesuai dengan penelitian Shi Limiao et al pada tahun 2014 yang menyatakan bahwa distribusi umur penderita dislipidemia pada rentang 40-49 tahun. Sebagian besar penderita tidak merokok sebanyak 19 orang (59\%) dan tidak memiliki riwayat diabetes melitus sebanyak 28 orang (87\%). ${ }^{8}$ 
Merokok merupakan salah satu faktor risiko terjadinya dislipidemia. Terdapat penelitian yang menyatakan bahwa perokok memiliki kolesterol plasma, trigliserida dan LDL yang tinggi serta HDL yang rendah dibandingkan orang yang tidak merokok. Rokok dapat menurunkan kadar apo A-I yang berperan dalam sintesis $\mathrm{HDL}$ sehingga mengganggu transpor kolesterol, meningkatkan oksidasi LDL dan inflamasi vaskular sehingga dapat menyebabkan terjadinya aterosklerosis yang berhubungan dengan peningkatan risiko kardiovaskular. ${ }^{9}$

Profil lipid bervariasi dan sangat berkaitan dengan diabetes melitus yang merupakan parameter penting terjadinya dislipidemia. Dislipidemia merupakan suatu abnormalitas metabolik yang prevalensinya bervariasi tergantung tipe dan tingkat keparahan diabetes, kontrol gula darah, usia dan faktor lain. Abnormalitas lipid yang paling sering terjadi pada penderita dislipidemia yaitu hipertrigliseridemia dan kolesterol HDL yang rendah dengan atau tanpa disertai peningkatan total kolesterol dan LDL. ${ }^{10}$

Selain merokok dan diabetes melitus, terdapat berbagai faktor risiko terjadinya dislipidemia baik primer yaitu defisiensi reseptor LDL, hiperlipidemia homozigot familial, defisiensi dan mutasi Apo A-1, mutasi Apo A-1 maupun penyebab dislipidemia sekunder seperti obesitas, hipertiroidisme, sindrom nefrotik, steroid anabolik, progestin, asupan lemak yang tinggi, aktivitas fisik yang kurang mungkin menjadi penyebab terjadinya dislipidemia pada sampel penelitian ini. Namun peneliti tidak menggali informasi lebih dalam berkaitan dengan penyebab dislipidemia yang terdapat pada sampel. ${ }^{11}$

Tabel 6. Korelasi antara plak arteri karotis, CIMT dan Total Calcium Score dengan derajat stenosis arteri koroner

\begin{tabular}{lcc}
\hline & $\mathrm{P}$ & $\mathrm{r}$ \\
\hline Plak arteri karotis dengan derajat stenosis arteri koroner & 0,017 & 0,418 \\
CIMT dengan derajat stenosis arteri koroner & $<0,0001$ & 0,65 \\
Total Calcium Score dengan derajat stenosis arteri koroner & $<0,0001$ & 0,882 \\
\hline
\end{tabular}

Pada penelitian ini, didapatkan karakteristik sampel penelitian dengan adanya plak pada arteri karotis sebanyak 7 orang (22\%) sedangkan yang tidak ada plak arteri karotis sebanyak 25 orang (78\%) Seluruh sampel yang memiliki plak juga memiliki stenosis pada arteri koroner dengan berbagai derajat stenosis sedangkan yang tidak memiliki plak arteri karotis, sebagian juga menunjukkan tidak ada stenosis pada arteri koroner sebanyak
14 orang dan yang lainnya sebanyak 11 orang memiliki stenosis pada arteri koroner dengan berbagai derajat stenosis. Sampel penelitian yang memiliki plak berumur $>40$ tahun dan sedikit lebih banyak pada perempuan sebanyak 4 (57\%) sampel. Suatu penelitian menyatakan bahwa prevalensi plak meningkat pada usia $>40$ tahun dan hampir sama kejadiannya baik pada laki-laki maupun perempuan. ${ }^{12}$ Pada penelitian ini 
didapatkan perempuan sedikit lebih banyak ditemukan plak arteri karotis dibandingkan dengan laki-laki dikarenakan prevalensi plak arteri karotis yang didapatkan sangat rendah sebanyak 7 (22\%) sampel sehingga tidak dapat menggambarkan demografi yang sebenarnya.

Pada tabel 6 memperlihatkan hasil analisis dengan uji Spearman, korelasi kejadian plak arteri karotis dengan derajat stenosis arteri koroner, menunjukkan bahwa ditemukan korelasi yang bermakna $(p<0,05)$ dan kekuatan korelasi sedang dengan nilai $r=0,418$. Yang mana adanya plak menunjukkan adanya stenosis pada arteri koroner, hal ini sesuai dengan penelitian yang pernah dilakukan Cohen dkk. pada tahun 2013 dimana juga menyebutkan bahwa kejadian plak merupakan penanda penting selain CIMT yang menunjukkan adanya stenosis pada arteri koroner. ${ }^{2}$ Namun pada penelitian ini belum dapat disimpulkan bagaimana plak itu memengaruhi tingginya derajat stenosis. Keterbatasan dalam penelitian ini yaitu rendahnya tingkat kejadian plak pada sampel dan perlu dilakukan penelitian lebih lanjut.

Hampir seluruh sampel mengalami penebalan pada nilai CIMT rata-rata dengan nilai mean $0,77 \mathrm{~mm}$. Hal ini sesuai dengan literatur bahwa penderita dislipidemia memiliki risiko aterosklerosis yang tinggi. Struktur yang pertama kali berubah dan dapat dideteksi adalah peningkatan ketebalan tunika intimamedia (Carotid Intima-Media
Thickness/CIMT). ${ }^{4} \quad$ Pada $\quad$ tabel 6 memperlihatkan hasil analisis dengan uji Spearman, korelasi CIMT dengan derajat stenosis arteri koroner, menunjukkan bahwa ditemukan korelasi yang bermakna $(p<0,05)$ dan kekuatan hubungan kuat dengan nilai $r=0,65$. Yang mana semakin tebal CIMT arteri karotis semakin berat stenosis arteri koroner. Hal ini sesuai dengan literatur bahwa ketebalan tunika intima-media merupakan penanda risiko aterosklerosis arteri koroner. ${ }^{4}$ Penelitian Fin (2009), Coskun (2009) dan Cohen et al (2013) juga membuktikan bahwa keadaan dinding arteri karotis mencerminkan keadaan dinding arteri koroner, sehingga penebalan CIMT atau terdapatnya plak arteri karotis dapat dipakai sebagai penanda terdapatnya aterosklerosis pada pembuluh darah jantung. ${ }^{2,13,14}$

Terdapat penelitian yang menyatakan bahwa plak pada arteri karotis memiliki korelasi yang kuat dengan penyakit jantung koroner dibandingkan CIMT ratarata dimana hampir seluruh pasien dengan plak pada arteri karotis memiliki stenosis pada arteri koroner sedangkan sebagian besar pasien yang tidak memiliki plak pada arteri karotis, juga tidak memiliki stenosis pada arteri koroner. ${ }^{2}$ Pada penelitian ini didapatkan CIMT rata-rata memiliki korelasi yang lebih kuat dibandingkan plak arteri karotis terhadap derajat stenosis, hal ini mungkin dikarenakan prevalensi plak arteri karotis pada orang Indonesia lebih sedikit dibandingkan penelitian yang pernah dilakukan di Amerika yang berkaitan dengan gaya hidup dan sampel 
penelitian yang lebih besar. Perlu dilakukan penelitian lebih lanjut mengenai prevalensi plak arteri karotis pada orang Indonesia agar dapat didapatkan data yang lebih akurat mengenai perbandingan korelasi antara plak arteri karotis dan CIMT rata-rata terhadap derajat stenosis arteri koroner. Ultrasonografi karotis sebagai alat diagnostik dan prediksi risiko memiliki keunggulan bersifat non invasif dan tidak memiliki efek samping radiasi. Pemeriksaan CIMT ini telah direkomendasikan sebagai pemeriksaan yang sangat berguna untuk stratifikasi risiko pada pasien yang belum jelas berisiko kejadian penyakit kardiovaskular maupun berisiko sedang. ${ }^{15}$

Total calcium score yang ditemukan pada sampel penelitian lebih banyak tidak ada sebanyak 17 (53\%) orang. Adanya calcium score menandakan suatu penyakit jantung koroner, dengan tanpa adanya nilai positif palsu. Pemeriksaan ini merupakan pemeriksaan MSCT tanpa menggunakan kontras dan menggunakan teknik ECGgated, sangat sensitif dalam mendeteksi adanya kalsium serta hanya dilakukan sekitar 10 menit. Skor kalsium akan meningkat dengan bertambahnya umur dan umumnya lebih tinggi prevalensinya pada laki-laki. Suatu calcium score 0 pada orang dewasa asimtomatik dan risiko rendah berarti kemungkinan kecil adanya plak aterosklerosis atau penyumbatan lumen yang signifikan dan berkaitan dengan suatu risiko yang sangat rendah (0,1\% per tahun) akan adanya kejadian penyakit kardiovaskular dalam 2-5 tahun.
Sebaliknya, dengan adanya total calcium score memastikan adanya plak aterosklerosis arteri koroner dan meningkatkan risiko penyakit jantung koroner. ${ }^{16}$ Budoff et al menyatakan bahwa sensitivitas calcium score sebesar 95\% dan spesifitas-nya sebesar $66 \%$.

Pada tabel 6 memperlihatkan hasil analisis dengan uji Spearman, korelasi total calcium score dengan derajat stenosis arteri koroner, menunjukkan bahwa ditemukan korelasi yang bermakna ( $p$ $<0,05)$ dan kekuatan korelasi sangat kuat dengan nilai (r) 0,882. Yang mana semakin tinggi nilai total calcium score semakin tinggi derajat stenosis arteri koroner. Pada berbagai penelitian berpendapat bahwa total calcium score merupakan suatu metode yang baik untuk mengukur adanya plak aterosklerosis namun tidak untuk mengukur derajat stenosis-nya dan juga penanda independen risiko kejadian kardiovaskular, mortalitas jantung sertai memberikan informasi prognostik tambahan bagi penanda risiko kardiovaskular lainnya. ${ }^{5,17}$

Adanya nilai total calcium score menunjukkan adanya penyakit arteri koroner namun tidak memprediksi obstruksi luminal. Nilai total calcium score 0 memiliki nilai prediktif negatif yang tinggi terhadap kejadian kardiovaskuler. ${ }^{16}$ Namun ada penelitian yang menyatakan bahwa nilai total calcium score 0 bukan berarti tidak ada stenosis pada arteri koroner, sebanyak 59\% dapat mengalami stenosis yang non signifikan dan 7,6\% mengalami stenosis yang signifikan. Pada 
penelitian ini didapatkan stenosis pada arteri koroner dengan total calcium score 0 sebanyak 3 sampel (9\%). Oleh karena itu sebaiknya dilakukan kombinasi MSCT angiografi koroner untuk menyingkirkan adanya stenosis akibat non-calcified plaque. ${ }^{18}$

Terdapat penelitian yang menyebutkan bahwa sensitivitas dan spesifitas MSCT kardiak masing-masing yaitu 100\% dan 91,3\%. MSCT kardiak 64-slice seperti pada RSUP dr. Wahidin Sudirohusodo ini memiliki sensitifitas masing-masing sebesar 90\%, 83\% dan 80,7\% untuk mendeteksi stenosis $\leq 50 \%$, stenosis $>50 \%$ dan stenosis $>75 \%$ serta spesifitas sebesar 96,5\%, 98,4\% dan 98,3\% dan tingkat akurasinya 96\%, 96,5\% dan 96,6\%. MSCT kardiak dengan kontras ini dapat digunakan sebagai pemeriksaan non invasif yang menjanjikan untuk mendeteksi stenosis arteri koroner dengan tingkat akurasi yang baik. ${ }^{19,20}$

Pada penelitian ini ditemukan bahwa terdapat korelasi yang sangat kuat antara total calcium score dengan derajat stenosis arteri koroner dibandingkan dengan plak dan CIMT rata-rata arteri karotis. Hal ini sesuai dengan beberapa penelitian yang menyatakan bahwa penilaian total calcium score sangat berguna dan sebagai penanda penyakit aterosklerosis kardiovaskular pada pasien asimptomatik risiko tinggi yang lebih superior dibandingkan evaluasi arteri karotis. Evaluasi arteri karotis dapat menjadi metode prediktif dalam pencegahan dan penilaian risiko penyakit aterosklerosis kardiovaskular. Tidak terdapat efek sinergis bila mengombinasikan evaluasi arteri karotis dengan penghitungan total calcium score. ${ }^{21,22}$

\section{SIMPULAN}

Terdapat korelasi antara kejadian plak arteri karotis, ketebalan tunika intimamedia arteri karotis berdasarkan ultrasonografi dan total calcium score dengan derajat stenosis arteri koroner berdasarkan MSCT-scan kardiak. Korelasi sangat kuat ditemukan pada total calcium score dengan derajat stenosis arteri koroner, meskipun demikian adanya plak dan ketebalan tunika intima-media arteri karotis berdasarkan ultrasonografi juga memiliki korelasi sehingga dapat dijadikan metode prediktif dalam penilaian risiko penyakit aterosklerosis kardiovaskular.

\section{UCAPAN TERIMA KASIH}

Kepada Kepala Departemen Radiologi Fakultas Kedokteran Universitas Hasanuddin yaitu Prof. Dr. dr. Bachtiar Murtala, Sp.Rad(K) dan Kepala Instalasi Radiologi Fakultas Kedokteran Universitas Hasanuddin yaitu dr. Luthfi Attamimi, Sp.Rad, keluarga, serta seluruh residen Radiologi Universitas Hasanuddin dan radiografer Instalasi Radiologi RSUP $\mathrm{dr}$. Wahidin Sudirohusodo. 


\section{DAFTAR PUSTAKA}

1. Yang C, Sun Z, Li Y, Ai J, Sun Q, Tian Y. The correlation between serum lipid profile with carotid intima-media thickness and plaque. BMC Cardiovascular Disorders. 2014; 14:181. doi: 10.1186/1471-2261-14-181.

2. Cohen GI, Aboufakher R, Bess R, Frank J, Othman M, Doan D, et al. Relationship between carotid disease on ultrasound and coronary disease on CT angiography. JACC Cardiovasc Imaging. 2013; 6(11):1160-7. doi: 10.1016/i.jemg.2013.06.007. [PubMed].

3. Jeevarethinam A, Venuraju S, Dumo A, Ruano S, Mehta VS, Roshental M, et al. Relationship between carotid atherosclerosis and coronary artery calcification in asymptomatic diabetic patients: A prospective multicenter study. Clin Cardiol. 2017; 40(9):752-758. doi: 10.1002/clc.22727. [PubMed].

4. Simova I. Intima-media thickness: Appropriate evaluation and proper measurement, described. ESC Council for Cardiology Practice. 2015; 13(21). Diunduh dari: [Link].

5. Neves PO, Andrade J, Monção H. Coronary artery calcium score: current status. Radiol Bras. 2017; 50(3):182-189. doi: 10.1590/0100-3984.2015.0235. [PMC free article].

6. Sayols-Baixeras S, Lluís-Ganella C, Lucas G, Elosua R. Pathogenesis of coronary artery disease: focus on genetic risk factors and identification of genetic variants. Appl Clin Genet. 2014; 7:15-32. doi: 10.2147/TACG.S35301. [PMC free article].

7. Lin CF, Chang YH, Chien SC, Lin YH, Yeh HY. Epidemiology of Dyslipidemia in the Asia Pacific Region. International Journal of Gerontology. 2018; 12(1):2-6. doi: 10.1016/j.ijge.2018.02.010.

8. Shi L, Hu J, Zhu K, Fu Y, Xia R, Hu X. Changes of prevalence of dyslipidemia among adults : a crosssectional study with a 2-year follow up in urban souteast China. Clin Lipidol. 2014; 9(1):33-47. doi: 10.2217/clp.13.82.

9. He BM, Zhao SP, Peng ZY. Effects of cigarette smoking on HDL quantity and function: Implications for atherosclerosis. J Cell Biochem. 2013; 114(11):2431-6. doi: 10.1002/jcb.24581.

10. Thapa SD, KC S, Gautam S, Gyawali D. Dyslipidemia in Type 2 Diabetes mellitus. Journal of Pathology of Nepal. 2017; 7(2):1149-1154. doi: 10.3126/jpn.v7i2.17978.

11. Gau GT, Wright RS. Pathophysiology, diagnosis, and management of dyslipidemia. Curr Probl Cardiol. 2006; 31(7):445-86. doi: 10.1016/i.cpcardiol.2006.03.001. [PubMed].

12. Sturlaugsdottir R, Aspelund T, Bjornsdottir G, Sigurdsson S, Thorsson B, Eiriksdottir G, et al. Prevalence and determinants of carotid plaque in the cross-sectional REFINE-Reykjavik study. BMJ Open 2016; 6(11):e012457. doi: 10.1136/bmjopen-2016-012457. [PubMed].

13. Finn AV, Kolodgie FD, Virmani R. Correlation between carotid intimal/medial thickness and atherosclerosis: a point of view from pathology. Arterioscler Thromb Vasc Biol. 2010; 30(2):17781. doi: 10.1161/ATVBAHA.108.173609. [PubMed].

14. Coskun U, Yildiz A. Esen OB, Baskurt M, Cakar MA, Kilickesmez KO, et al. Relationship between carotid intima-media thickness and coronary angiographic findings: a prospective study. Cardiovasc Ultrasound. 2009; 7:59. doi: 10.1186/1476-7120-7-59. [PubMed].

15. Robertson CM, Gerry F, Fowkes R, Price JF. Carotid intima-media thickness and the prediction of vascular events. Vasc Med. 2012; 17(4):239-48. doi: 10.1177/1358863X12445103. [PubMed]. 
16. Shah NR, Coulter SA. An evidence-based guide for coronary calcium scoring in asymptomatic patients without coronary heart disease. Tex Heart Inst J. 2012; 39(2):240-2. [PubMed] [PMC free article].

17. Zaid M, Fujiyoshi A, Kadota A, Abbott R D, Miura K. Coronary Artery Calcium and Carotid Artery Intima Media Thickness and Plaque: Clinical Use in Need of Clarification. J Atheroscler Thromb. 2017; 24(3):227-239. doi: 10.5551/jat.RV16005. [PMC free article].

18. Hanifehpour R, Motevalli M, Ghanaati H, Shahriari M, Aliyari Ghasabeh M. Diagnostic Accuracy of Coronary Calcium Score Less than 100 in Excluding Coronary Artery Disease. Iran J Radiol. 2016; 13(2):e16705. doi: 10.5812/iranjradiol.16705. [PubMed].

19. Joshi H, Shah R, Prajapati J, Bhangdiya V, Shah J, Kandre Y, et al. Diagnostic Accuracy of Computed Tomography Angiography as Compared to Conventional Angiography in Patients Undergoing Noncoronary Cardiac Surgery. Heart Views. 2016; 17(3):88-91. doi: 10.4103/1995-705X.192555. [PubMed].

20. Mannan M, Bashar MA, Mohammad J, Jahan MU, Momenuzzaman NA, Haque MA. Comparison of coronary $\mathrm{CT}$ angiography with conventional coronary angiography in the diagnosis of coronary artery disease. Bangladesh Med Res Counc Bull. 2014; 40(1):31-5. [PubMed].

21. Kim GH, Youn HJ, Choi YS, Jung HO, Chung WS, Kim CM. Carotid artery evaluation and coronary calcium score: which is better for the diagnosis and prevention of atherosclerotic cardiovascular disease?. Int J Clin Exp Med. 2015; 8(10):18591-18600. [PMC free article].

22. Gepner AD, Young R, Delaney JA, Budoff MJ, Polak JF, Blaha MJ, et al. Comparison of Carotid Plaque Score and Coronary Artery Calcium Score for Predicting Cardiovascular Disease Events: The Multi-Ethnic Study of Atherosclerosis. J Am Heart Assoc. 2017; 6(2):e005179. doi: 10.1161/JAHA.116.005179. [PubMed]. 